\title{
INSTITUTO VENEZOLANO DE INVESTIGACIONES CIENTIFICAS NATURAL RADIOCARBON MEASUREMENTS IV
}

\author{
M. A. TAMERS
}

Instituto Venezolano de Investigaciones Científicas, Department of Chemistry, Caracas, Venezuela

The laboratory renewed operations in January, 1968 after a year's inactivity due to the absence of the head, who was on leave at the University of Bonn. Synthesized benzene continues as the dating medium, but various improvements have been made on the chemical method in order to increase capacity. Combustions are no longer carried out for normal materials. Instead, charcoal samples are used directly (after the usual pretreatment) and wood, plants, cloth, etc. are carbonized in a nitrogen atmosphere. Charring is a considerably more rapid procedure than combustion since it eliminates the $\mathrm{CO}_{2}$ collection, carbonate precipitation, and filtration steps. The charcoal then is reacted with molten lithium metal. Also, it was found that carbonates are attacked directly by hot lithium to produce carbides and the preliminary generation of $\mathrm{CO}_{2}$ gas is not indispensable. The carbide, cooled to room temperature, is reacted with old water (IVIC-317, Radiocarbon, 1967, v. 9, p. 240), the acetylene separated from hydrogen in a double liquid nitrogen-cooled trap, and benzene produced with a chromium activated silica-alumina catalyst.

The cylindrical stainless steel lithium reaction vessel is shown in Fig. 1. This shape permits the concentration of the sample with the molten lithium, heated to ca. $550^{\circ} \mathrm{C}$ with a single Meeker burner. The system is previously evacuated, but the pump is not connected during the actual reaction. A small amount of gas appears, probably hydrogen generated from traces of water, and this facilitates the production of carbide by conducting heat throughout the heterogeneous mixture. The exothermic reaction can be observed in the lower portion of the vessel by the change from a dull to bright red glow. The pressure is monitored during this period and if more than $1 / 2$ atm is attained, the vacuum pump is reconnected. The reaction is completed in a few minutes, the burner removed, and the vessel continuously pumped during the cooling period. An excess of lithium is avoided since this lengthens considerably the time necessary for the hydrolysis.

Addition of 21 . tritium-free water generates acetylene, which is purified by passing over phosphoric acid-soaked glass beads and a dry icecooled trap. The large excess of water is necessary to dilute the lithium ion concentration, permitting a fast reaction with lithium metal. The cyclization to benzene is accomplished by a contact catalyst (Pietig and Scharpenseel, 1966) previously dried at $250^{\circ} \mathrm{C}$ and maintained at ca. $75^{\circ} \mathrm{C}$ during the operation. At this temperature the acetylene is absorbed as fast as it can be evaporated from the liquid nitrogen-cooled steel trap. 


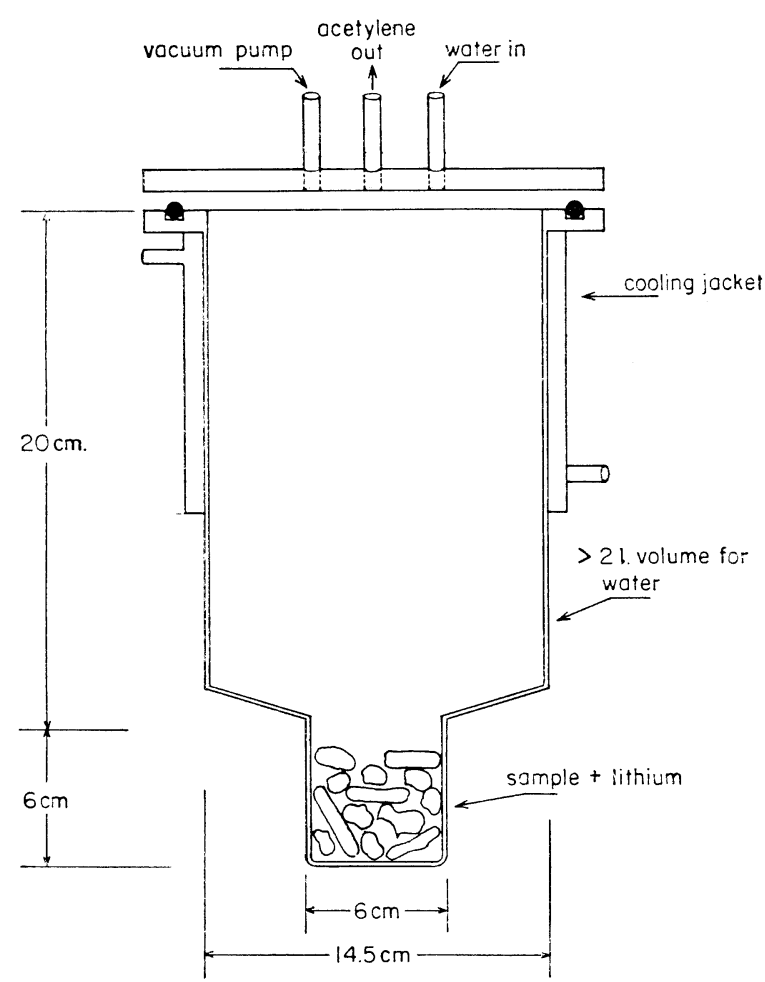

Figure 1.

An extraction of the benzene at $150^{\circ} \mathrm{C}$ completes the process. The syntheses are summarized by the following equations:

$$
\begin{aligned}
& 2 \mathrm{C}+2 \mathrm{Li} \stackrel{\triangle}{\longrightarrow} \mathrm{Li}_{2} \mathrm{C}_{2} \\
& \text { - or - } \\
& 2 \mathrm{CaCO}_{3}+10 \mathrm{Li} \stackrel{\triangle}{\rightarrow} \mathrm{Li}_{2} \mathrm{C}_{2}+2 \mathrm{CaO}+4 \mathrm{Li}_{2} \mathrm{O} \\
& \mathrm{Li}_{2} \mathrm{C}_{2}+\mathrm{H}_{2} \mathrm{O} \longrightarrow \mathrm{C}_{2 .} \mathrm{H}_{2}+\mathrm{Li}_{2} \mathrm{O} \\
& 3 \mathrm{C}_{12} \mathrm{H}_{2} \stackrel{\text { catalyst }}{\longrightarrow} \mathrm{C}_{6} \mathrm{H}_{6}
\end{aligned}
$$

One technician's production is up to 9 samples/week, in addition to his other duties. The individual processing time is approx. $3 \mathrm{hrs}$, not requiring the continuous attention of the worker.

The small counting chamber contains $3 \mathrm{cc}$ synthesized benzene, 1 cc coal tar-derived toluene and concentrations of $0.4 \%$ and $0.01 \%$ PPO and dimethyl-POPOP. The net modern count rate is $21.2 \mathrm{cpm}$ and the background is $7.4 \mathrm{cpm}$. This arrangement represents a compromise suitable for small samples. The use of greater amounts of benzene increases the sensitivity, but the higher background would be a disadvantage for specimens with low carbon contents. 
In agreement with international conventions, all calculations of dates are made with the radiocarbon half-life taken as $5568 \mathrm{yr}$ and the modern standard as $95 \%$ of the activity of the NBS oxalic acid. The errors quoted are the standard deviations originating in the random nature of the radioactive disintegration process. Apparent ages less than $100 \mathrm{yr}$ are designated as "Modern".

\section{ACKNOWLEDGMENTS}

Cooperation and support from the I.V.I.C. Dept. of Chem., Dr. G. Chuchani, head, and Dept. of Anthropol., Prof. J. M. Cruxent, head, continue to be of prime importance. Routine chemical procedures and the benzene syntheses are done by Mr. V. García. Mr. A. Russo maintains the electronics.

\section{SAMPLE DESCRIPTIONS}

\section{GROUND WATER SAMPLES}

The program of repeated sampling of selected aquifers in Venezuela is now going into its third year. This is being done principally to elucidate ground water movements in cases where samples are modern and reflect contamination from nuclear weapons tests. Since there are at least two major peaks in the radiocarbon excess curve for Venezuela (Tamers, 1967b), individual activity values cannot be unambiguously assigned to specific years. Nevertheless, trends seen from annual samplings can be fitted more clearly to the contamination curve and average flow velocities deduced (Tamers, 1969). The Maracaibo samples are apart from this study.

Radiocarbon contents are reported as $\%$ of modern without correction for limestone dilution. Samples coll. 1966-1968, and subm. by members of the Radiocarbon Lab.

\begin{tabular}{|c|c|c|}
\hline & $\begin{array}{c}\text { Collection } \\
\text { (day/month/yr) }\end{array}$ & $\begin{array}{c}\mathrm{C}^{14} \\
(\% \text { of modern })\end{array}$ \\
\hline $\begin{array}{l}\text { Wells of Valencia Lake Basin } \\
\text { IVIC-297. Macapo } \\
\quad\left(10^{\circ} 6^{\prime} \text { N Lat, } 67^{\circ} 37^{\prime} \text { W Long }\right)\end{array}$ & $11 / 3 / 66$ & $88.4 \pm 0.7$ \\
\hline $\begin{array}{l}\text { IVIC-302. Mariara 2 } \\
\left(10^{\circ} 13^{\prime} \text { N Lat, } 67^{\circ} 43^{\prime} \text { W Long }\right)\end{array}$ & $18 / 3 / 66$ & $97.5 \pm 0.8$ \\
\hline $\begin{array}{l}\text { IVIC-303. Tapatapa } \\
\left(10^{\circ} 15^{\prime} \text { N Lat, } 67^{\circ} 38^{\prime} \mathrm{W} \text { Long }\right)\end{array}$ & $18 / 3 / 66$ & $68.0 \pm 0.5$ \\
\hline $\begin{array}{l}\text { IVIC-311. Cagua } 1 \\
\quad\left(10^{\circ} 11^{\prime} \text { N Lat, } 67^{\circ} 28^{\prime} \text { W Long }\right)\end{array}$ & $24 / 3 / 66$ & $93.4 \pm 0.7$ \\
\hline $\begin{array}{l}\text { IVIC-327. Fabrica Unica } \\
\left(10^{\circ} 11^{\prime} \text { N Lat, } 67^{\circ} 58^{\prime} \mathrm{W} \text { Long }\right)\end{array}$ & $12 / 4 / 66$ & $67.0 \pm 1.4$ \\
\hline $\begin{array}{l}\text { IVIC-335. Cascabel } \\
\left(10^{\circ} 7^{\prime} \text { N Lat, } 67^{\circ} 55^{\prime} \text { W Long }\right)\end{array}$ & $25 / 4 / 66$ & $67.4 \pm 0.5$ \\
\hline
\end{tabular}


IVIC-337. La Croquera

$\left(10^{\circ} 10^{\prime} \mathrm{N}\right.$ Lat, $67^{\circ} 32^{\prime} \mathrm{W}$ Long)

IVIC-338. Mamon Macho

( $10^{\circ} 10^{\prime} \mathrm{N}$ Lat, $67^{\circ} 32^{\prime} \mathrm{W}$ Long)

IVIC-339. San Joaquín

( $10^{\circ} 16^{\prime} \mathrm{N}$ Lat, $67^{\circ} 47^{\prime} \mathrm{W}$ Long)

IVIC-340. Guacara

$\left(10^{\circ} 14^{\prime} \mathrm{N}\right.$ Lat, $67^{\circ} 53^{\prime} \mathrm{W}$ Long)

IVIC-341. Mocundo

(10 $12^{\prime}$ N Lat, $67^{\circ} 53^{\prime} \mathrm{W}$ Long)

IVIC-403. Güigüe 2

(10 $5^{\prime} \mathrm{N}$ Lat, $67^{\circ} 47^{\prime} \mathrm{W}$ Long)

IVIC-404. Güigüe 3

( $10^{\circ} 5^{\prime} \mathrm{N}$ Lat, $67^{\circ} 47^{\prime} \mathrm{W}$ Long)

IVIC-405. El Trompillo

( $10^{\circ} 4^{\prime} \mathrm{N}$ Lat, $67^{\circ} 46^{\prime} \mathrm{W}$ Long)

IVIC-406. Mariara 1

(10 $10^{\circ} 15^{\prime} \mathrm{N}$ Lat, $67^{\circ} 43^{\prime} \mathrm{W}$ Long)

IVIC-407. Mariara 2

(10 $10^{\circ}$ N Lat, $67^{\circ} 43^{\prime} \mathrm{W}$ Long)

IVIC-408. San Francisco de Asis ( $10^{\circ} 5^{\prime} \mathrm{N}$ Lat, $67^{\circ} 33^{\prime} \mathrm{W}$ Long)

IVIC-409. 19 de Abril

(10 $10^{\circ} 3^{\prime} \mathrm{N}$ Lat, $67^{\circ} 31^{\prime} \mathrm{W}$ Long)

IVIC-410. Fund. Shell, Pozo

\section{Pequeño}

(10 $0^{\circ} 11^{\prime}$ N Lat, $67^{\circ} 28^{\prime} \mathrm{W}$ Long)

IVIC-411. Tocorón

( $10^{\circ} 6^{\prime} \mathrm{N}$ Lat, $67^{\circ} 35^{\prime} \mathrm{W}$ Long)

IVIC-425. Mariara 1

(10 $15^{\prime}$ N Lat, $67^{\circ} 43^{\prime} \mathrm{W}$ Long)

IVIC-426. Mariara 2

(10 $13^{\circ}$ N Lat, $67^{\circ} 43^{\prime} \mathrm{W}$ Long)

IVIC-427. San Francisco de Asis ( $10^{\circ} 5^{\prime} \mathrm{N}$ Lat, $67^{\circ} 33^{\prime} \mathrm{W}$ Long)

IVIC-428. Tocorón

( $10^{\circ} 6^{\prime} \mathrm{N}$ Lat, $67^{\circ} 35^{\prime} \mathrm{W}$ Long)
Collection

(day/month/yr)

$5 / 5 / 66$

$5 / 5 / 66$

$5 / 5 / 66$

$5 / 5 / 66$

$5 / 5 / 66$

$2 / 2 / 67$

$2 / 2 / 67$

$2 / 2 / 67$

$2 / 2 / 67$

$2 / 2 / 67$

$27 / 2 / 67$

$27 / 2 / 67$

$27 / 2 / 67$

$27 / 2 / 67$

$28 / 2 / 68$

$28 / 2 / 68$

$28 / 2 / 68$

$28 / 2 / 68$
$\mathrm{C}^{14}$

(\% of modern)

$68.4 \pm 0.6$

$71.2 \pm 0.7$

$72.5 \pm 0.7$

$74.8 \pm 0.7$

$69.7 \pm 0.7$

$114.9 \pm 1.0$

$96.9 \pm 0.8$

$97.3 \pm 0.8$

$95.3 \pm 0.8$

$93.9 \pm 0.8$

$104.1 \pm 1.1$

$94.8 \pm 0.8$

$83.7 \pm 0.8$

$96.3 \pm 0.8$

$92.6 \pm 0.8$

$97.4 \pm 0.8$

$105.0 \pm 0.8$

$103.2 \pm 0.8$ 
IVIC-429. El Trompillo (10 $4^{\prime} \mathrm{N}$ Lat, $67^{\circ} 46^{\prime} \mathrm{W} \mathrm{W}^{\prime}$ Long)

IVIC-430. Güigüe 1 ( $10^{\circ} 5^{\prime} \mathrm{N}$ Lat, $67^{\circ} 47^{\prime} \mathrm{W} \mathrm{W}^{\prime}$ Long)

IVIC-431. Güiguie 3 ( $10^{\circ} 5^{\prime} \mathrm{N}$ Lat, $67^{\circ} 47^{\prime} \mathrm{W}$ Long)

IVIC-506. Mariara 1 ( $10^{\circ} 15^{\prime} \mathrm{N}$ Lat, $67^{\circ} 43^{\prime} \mathrm{W}$ Long)

IVIC-507. Mariara 2 ( $10^{\circ} 13^{\prime} \mathrm{N}$ Lat, $67^{\circ} 43^{\prime} \mathrm{W}$ Long)

IVIC-508. El Trompillo (10 $4^{\prime} \mathrm{N}$ Lat, $67^{\circ} 46^{\prime} \mathrm{W}$ Long)

IVIC-509. Güiguie ( $10^{\circ} 5^{\prime} \mathrm{N}$ Lat, $67^{\circ} 47^{\prime} \mathrm{W}$ Long)

IVIC-510. Güigüe 3

( $10^{\circ} 5^{\prime} \mathrm{N}$ Lat, $67^{\circ} 47^{\prime} \mathrm{W}$ Long)

Barquisimeto Wells

IVIC-346. El Jebe 6 ( $10^{\circ} 7^{\prime} \mathrm{N}$ Lat, $69^{\circ} 15^{\prime} \mathrm{W}$ Long)

IVIC-347. El Jebe 1 (10 $0^{\circ} 7^{\prime} \mathrm{N}$ Lat, $69^{\circ} 15^{\prime} \mathrm{W}$ Long)

IVIC-348. El Jebe 2 $\left(10^{\circ} 7^{\prime} \mathrm{N}\right.$ Lat, $69^{\circ} 15^{\prime} \mathrm{W}$ Long)

IVIC-349. Corvaia (10 ${ }^{\circ} 7^{\prime} \mathrm{N}$ Lat, $69^{\circ} 15^{\prime} \mathrm{W}$ ' Long)

IVIC-350. San Martin ( $10^{\circ} 7^{\prime} \mathrm{N}$ Lat, $69^{\circ} 15^{\prime} \mathrm{W}$ Long)

IVIC-351. Macuto 3 ( $10^{\circ} 3^{\prime} \mathrm{N}$ Lat, $69^{\circ} 19^{\prime} \mathrm{W}$ Long)

IVIC-352. Macuto 2 (10 $3^{\circ} \mathrm{N}$ Lat, $69^{\circ} 19^{\prime} \mathrm{W}$ Long)

IVIC-353. Macuto 1 ( $10^{\circ} 3^{\prime} \mathrm{N}$ Lat, $69^{\circ} 19^{\prime} \mathrm{W}$ Long)

IVIC-354. Macuto 4 (10 $3^{\prime}$ N Lat, $69^{\circ} 19^{\prime} \mathrm{W}$ L Long)
Collection

$\mathrm{C}^{14}$

(day/month/yr)

$11 / 3 / 68$ ( $\%$ of modern)

$11 / 3 / 68$

$99.5 \pm 0.8$

$11 / 3 / 68$

$105.0 \pm 0.9$

$4 / 9 / 68$

$92.2 \pm 0.8$

$4 / 9 / 68$

$92.2 \pm 0.8$

$4 / 9 / 68$

$100.3 \pm 0.8$

$4 / 9 / 68$

$4 / 9 / 68$

$99.6 \pm 0.8$

$30 / 5 / 66$

$30 / 5 / 66$

$30 / 5 / 66$

$30 / 5 / 66$

$30 / 5 / 66$

$31 / 5 / 66$

$31 / 5 / 66$

$31 / 5 / 66$

$31 / 5 / 66$
$90.0 \pm 0.8$

$62.9 \pm 0.6$

$49.6 \pm 0.5$

$24.0 \pm 0.6$

$80.3 \pm 0.7$

$25.2 \pm 0.6$

$75.4 \pm 0.7$

$77.1 \pm 0.7$

$86.9 \pm 0.7$ 


\author{
IVIC-355. Macuto 5 \\ ( $10^{\circ} 3^{\prime} \mathrm{N}$ Lat, $69^{\circ} 19^{\prime} \mathrm{W}$ Long) \\ IVIC-412. Macuto 1 \\ (10 $3^{\prime} \mathrm{N}$ Lat, $69^{\circ} 19^{\prime} \mathrm{W}$ Long) \\ IVIC-413. Macuto 2 \\ $\left(10^{\circ} 3^{\prime} \mathrm{N}\right.$ Lat, $69^{\circ} 19^{\prime} \mathrm{W}$ Long $)$ \\ IVIC-414. Macuto 6 \\ $\left(10^{\circ} 3^{\prime} \mathrm{N}\right.$ Lat, $69^{\circ} 19^{\prime} \mathrm{W}$ Long) \\ IVIC-415. Macuto 7 \\ (10 $3^{\prime} \mathrm{N}$ Lat, $69^{\circ} 19^{\prime} \mathrm{W}$ Long) \\ IVIC-416. Macuto 5 \\ $\left(10^{\circ} 3^{\prime} \mathrm{N}\right.$ Lat, $69^{\circ} 19^{\prime} \mathrm{W}$ Long) \\ IVIC-439. Macuto 1 \\ ( $10^{\circ} 3^{\prime} \mathrm{N}$ Lat, $69^{\circ} 19^{\prime} \mathrm{W}$ Long) \\ IVIC-440. Macuto 2 \\ (10 $13^{\circ}$ ' N Lat, $69^{\circ} 19^{\prime} \mathrm{W}$ Long) \\ IVIC-441. Macuto 3 \\ $\left(10^{\circ} 3^{\prime} \mathrm{N}\right.$ Lat, $69^{\circ} 19^{\prime} \mathrm{W}$ Long) \\ IVIC-444. Macuto 6 \\ (10 $0^{\circ}$ ' N Lat, $69^{\circ} 19^{\prime} \mathrm{W}$ Long) \\ IVIC-445. Macuto 7 \\ ( $10^{\circ} 3^{\prime} \mathrm{N}$ Lat, $69^{\circ} 19^{\prime} \mathrm{W}$ Long) \\ Maracaibo Aquifer Wells \\ IVIC-490. Campo 1, Pozo 28 \\ (10 $33^{\prime}$ N Lat, $71^{\circ} 42.5^{\prime}$ W Long) \\ IVIC-491. Campo 1, Pozo 22 \\ (10 $32^{\prime} \mathrm{N}$ Lat, $71^{\circ} 43^{\prime} \mathrm{W}$ Long) \\ IVIC-492. Campo 2, Pozo 6 \\ (10 $30^{\prime} \mathrm{N}$ Lat, $71^{\circ} 48^{\prime} \mathrm{W}$ Long) \\ IVIC-493. Campo 2, Pozo 9 \\ (10 $29^{\prime} \mathrm{N}$ Lat, $71^{\circ} 48^{\prime} \mathrm{W}$ Long) \\ IVIC-494. Campo 3A, Pozo 1 \\ (103' $\mathrm{N}$ Lat, $71^{\circ} 43^{\prime} \mathrm{W}$ Long) \\ IVIC-495. La Cañada \\ (10 $25^{\prime} \mathrm{N}$ Lat, $71^{\circ} 41^{\prime} \mathrm{W}$ Long)
}

Collection

(day/month/yr)

$\mathrm{C}^{14}$

$31 / 5 / 66$

(\% of modern)

$\begin{array}{ll}31 / 5 / 66 & \mathbf{7 8 . 1} \pm \mathbf{0 . 7} \\ -/ 5 / 67 & \mathbf{8 6 . 7} \pm \mathbf{0 . 7} \\ -/ 5 / 67 & \mathbf{8 5 . 4} \pm \mathbf{0 . 7} \\ -/ 5 / 67 & \mathbf{8 6 . 7} \pm \mathbf{0 . 7} \\ -/ 5 / 67 & \mathbf{9 9 . 1} \pm \mathbf{0 . 8} \\ -/ 5 / 67 & \mathbf{8 3 . 1} \pm \mathbf{0 . 7} \\ 8 / 5 / 68 & \mathbf{8 8 . 5} \pm \mathbf{0 . 7} \\ 7 / 5 / 68 & \mathbf{8 1 . 6} \pm \mathbf{0 . 7} \\ 7 / 5 / 68 & \mathbf{7 5 . 3} \pm \mathbf{0 . 7} \\ 7 / 5 / 68 & \mathbf{8 1 . 1} \pm \mathbf{0 . 7} \\ 7 / 5 / 68 & \mathbf{8 2 . 4} \pm \mathbf{0 . 7}\end{array}$

$15 / 8 / 68$

$23.1 \pm 0.4$

$15 / 8 / 68$

$27.7 \pm 0.4$

$15 / 8 / 68$

$29.7 \pm 0.4$

$15 / 8 / 68$

$24.2 \pm 0.4$

$15 / 8 / 68$

$20.1 \pm 0.4$

$15 / 8 / 68$

$2.50 \pm 0.29$ 


\section{Indo-Hispanic Epoch}

\section{ARCHAEOLOGIC SAMPLES}

\section{A. Venezuela}

IVIC-284. Araya, Pozo del Rey 3

A.D. 1710

Charcoal from Pit $3,0.25$ to $0.50 \mathrm{~m}$ below surface on Peninsula of Araya, Venezuela (10 $35^{\prime} \mathrm{N}$ Lat, $64^{\circ} 15^{\prime} \mathrm{W}$ Long). Assoc. with Dutch and Spanish majolica of Indo-Hispanic Period V (Rouse and Cruxent, 1963a). Previous dates for this site were $450 \pm 60$ B.P. and $230 \pm 60$ B.P. (IVIC282 and IVIC-283, Radiocarbon, 1967, v. 9, p. 240-241). Coll. 1966 and subm. by José Cruxent, I.V.I.C., who estimated date ca. A.D. 1650. Comment: in agreement with submitter's estimation.

\section{IVIC-287. Araya, Pozo del Rey 6, 0.25 to $0.50 \mathrm{~m}$ A.D. 1720

$$
340 \pm 60
$$

$$
230 \pm 60
$$

\section{IVIC-286. Araya, Pozo slel Rey, 6, 0.75 to $0.90 \mathrm{~m}$ A.D. 1610}

Charcoal samples from Pit 6 on Peninsula of Araya, Venezuela $\left(10^{\circ}\right.$ $35^{\prime} \mathrm{N}$ Lat, $64^{\circ} 15^{\prime} \mathrm{W}$ Long). Assoc. with Dutch and Spanish majolica and glass. The lower lying material should be from 0 to $50 \mathrm{yr}$ older than that of upper layer, which would date from same time as IVIC-284. Coll. 1966 and subm. by José Cruxent. Comment: in agreement with submitter's estimation.

\section{IVIC-288. Maurica 6}

\section{A.D. 1400}

$\mathbf{5 5 0} \pm \mathbf{7 0}$

Charcoal from Pit $6,0.00$ to $0.25 \mathrm{~m}$ below surface, $2 \mathrm{~km}$ E of Barcelona, Venezuela $\left(10^{\circ} 10^{\prime} \mathrm{N}\right.$ Lat, $64^{\circ} 45^{\prime} \mathrm{W}$ Long). Control on historic date for city of San Cristobal de los Cumanagotos. Other surface sample clates for this site were $490 \pm 50$ B.P. and $530 \pm 60$ B.P. (IVIC-285 and IVIC-289, Radiocarbon, 1967, v. 9, p. 241). Coll. 1966 and subm. by José Cruxent. Comment: indistinguishable from previous dates. But in disagreement with estimated date of A.D. 1580-1640. In any case, Maurica should be older than Araya.

IVIC-318A. Lagun-1, A

Modern

IVIC-318B. Lagun-1, B

$$
170 \pm 80
$$

A.D. 1780

Wood from Spanish colonial ruins in Hacienda Lagunetica, La Laguneta, State of Miranda, Venezuela ( $10^{\circ} 20 \mathrm{~N}$ Lat, $67^{\circ} 5^{\prime} \mathrm{W}$ Long). Assoc. with type of architecture believed to date from 16th or 17 th cencuries. Comment: age too young, but this could be due to abnormally high radiocarbon concentrations seen in 17 th century (Stuiver and Suess, 1966).

IVIC-320. Araya, Pozo del Rey 12, 0.25 to $0.50 \mathrm{~m}$ Modern

IVIC-321. Araya, Pozo del Rey 12, 0.50 to 0.75 m A.D. 1810 
IVIC-322. Araya, Pozo del Rey 12, $1.00 \mathrm{~m}$

Modern

IVIC-323. Araya, Pozo del Rey 12, 1.00 to $1.25 \mathrm{~m}$ A.D. 1730

$220 \pm 60$

IVIC-324. Araya, Pozo del Rey 12, 1.25 to $1.50 \mathrm{~m}$

Modern

Charcoal samples from Pit 12 of Hacienda Salina, Municipality Araya, State of Sucre, Venezuela (64. $20^{\prime} \mathrm{N}$ Lat, $10^{\circ} 30^{\prime} \mathrm{W}$ Long). Assoc. with Dutch and Indian artifacts that should date between 17th and 18th centuries. Coll. 1966 and subm. by José Cruxent. Comment: ca. A.D. 1700 there was a tendency for increase in deposition rate of radiocarbon that produced abnormalities as large as $2.8 \%$ (Broecker, Olson, and Bird, $1959)$, resulting in observation of samples from this period having radiocarbon ages as young as $<100 \mathrm{yr}$ old, i.e., "Modern." Above samples are probably all approx. same age, ca. $230 \pm 50$ B.P., in agreement with submitter's estimate.

\section{Neo-Indian Epoch}

IVIC-356. Miquimú 2 and 3

$$
\mathbf{4 7 0} \pm 70
$$

Small charcoal sample from Pit 5, Sec. B, $1.20 \mathrm{~m}$ below surface and larger amount taken from fragment of crumbling ravine. In village of Miquimú, state of Trujillo, Venezuela ( $9^{\circ} 35.6^{\prime} \mathrm{N}$ Lat, $70^{\circ} 15.2^{\prime} \mathrm{W}$ Long). Same site dated previously at $1300 \pm 170$ B.P. (Wagner, 1967). Assoc. with typical bat wing pendants of metamorphosed chert and Miquimú style ceramic. Comment: (E.W.): does not confirm antiquity of IVIC-179, but this might be due to presence of intrusive charcoal from ravine.

\section{IVIC-449. El Mocao Alto 2, 0.25 to $0.50 \mathrm{~m}$}

\section{IVIC-450. El Mocao Alto $2,0.50$ to $0.75 \mathrm{~m}$}

$1120 \pm 150$

Charcoal samples (IVIC-450 very small) from Pit 2, Sec. B of site 1 $\mathrm{km}$ SE of Mucuchies, state of Mérida, Venezuela $\left(9^{\circ} 19^{\prime} \mathrm{N}\right.$ Lat, $71^{\circ} 8^{\prime}$ W Long). Assoc. with grinding stones and coarse pottery in lower level. Coll. 1968 and subm. by Erika Wagner. These are 1st $\mathrm{C}^{14}$ dates for state of Mérida. Comment: (E.W.) in agreement with dates for W Venezuela-Periods III-V, A.D. 300 to present.

\section{IVIC-432. El Mocao Alto C 4, 0.25 to $0.50 \mathrm{~m}$}

\section{IVIC-451. El Mocao Alto C 4, 0.75 to $1.00 \mathrm{~m}$}

A.D. 980

$570 \pm 60$

Charcoal from Pit 4, Sec. C of excavation ca. $4 \mathrm{~km}$ SE Mucuchies, separated by Chama R.; state of Mérida, Venezuela $\left(9^{\circ} 19^{\prime} \mathrm{N}\right.$ Lat, $71^{\circ} \mathrm{3}^{\prime}$ W Long). Assoc. with ceramic fragments, charred deer and rabbit bones, worked stone chips, terrestrial snail shells, and bat wing pendants of quartz, mica, calcite, and other minerals. Coll. 1968 and subm. by Erika 
Wagner. Comment (E.W.): dates agree with others from Venezuelan Andes.

\section{IVIC-481. El Mocao Alto, bones}

$230 \pm 40$

Human bones, not charred, 0.75 to $1.25 \mathrm{~m}$ below surface in same site as previous Mocao Alto samples $\left(9^{\circ} 19^{\prime} \mathrm{N}\right.$ Lat, $71^{\circ} 8^{\prime} \mathrm{W}$ Long) and with similar cultural artifacts. Possibility of intrusive post-columbian burial. Coll. 1968 and subm. Erika Wagner. Sample completely dissolved in hydrochloric acid to insure removal of carbonates. Organic carbon content $3.3 \%$. Measurement repeated with results $210 \pm 60$ and $250 \pm$ 60 в.P. Comment (E.W.): date reasonable and confirms evidence indicating recent origin of burial.

\section{IVIC-448. La Era Nueva $10,0.25$ to $0.50 \mathrm{~m}$}

$$
\begin{array}{r}
970 \pm 70 \\
\text { A.D. } 980 \\
870 \pm 60 \\
\text { A.D. } 1080
\end{array}
$$

IVIC-433. La Era Nueva 10, 0.50 to $0.75 \mathrm{~m}$

Charcoal samples from Pit. 10, Sec. E of site ca. $8 \mathrm{~km}$ SE Mucuchies, state of Mérida, Venezuela $\left(9^{\circ} 18^{\prime} \mathrm{N}\right.$ Lat, $71^{\circ} 10^{\prime} \mathrm{W}$ Long). Assoc. with ceramic fragments, some of which are not typical for region and were probably obtained through commerce. Grinding stones also present in lower level. Coll. 1968 and subm. by Erika Wagner. Comment (E.W.): dates agree with rest of $\mathrm{W}$ Venezuela and with those of sites that have pottery similar to trade sherds.

\section{IVIC-446. La Era Nueva 7}

$$
1060 \pm 70
$$

Charcoal from Pit 7, Sec. E, 0.25 to $0.50 \mathrm{~m}$ below surface of excavation ca. $8 \mathrm{~km} \mathrm{SE}$ Mucuchies, state of Mérida, Venezuela $\left(9^{\circ} 18^{\prime} \mathrm{N}\right.$ Lat, $71^{\circ} 10^{\prime}$ W Long). Artifacts similar to those of IVIC-439. Coll. 1968 and subm. by Erika Wagner. Comment (E.W.): date reasonable.

\section{IVIC-447. La Era Nueva 9}

Charcoal from Pit 9, Sec. E, 0.25 to $0.50 \mathrm{~m}$ below surface ca. $8 \mathrm{~km}$ SE Mucuchies, State of Mérida, Venezuela $\left(9^{\circ} 18^{\prime} \mathrm{N} \mathrm{Lat,} 71^{\circ} 10^{\prime} \mathrm{W}\right.$ Long). Assoc. artifacts include coarse pottery and terrestrial snail shells. Coll. 1968 and subm. by Erika Wagner. Comment (E.W.): date reasonable.

\section{La Calzada series}

Specimens from artificial mound, No. 1, $12.5 \mathrm{~m}$ high, base diam. $80 \mathrm{~m}$, ca. $1.5 \mathrm{~km} \mathrm{~W}$ of Hato de La Calzada, state of Barinas, Venezuela $\left(8^{\circ} 2^{\prime} \mathrm{N}\right.$ Lat, $70^{\circ} 8^{\prime} \mathrm{W}$ Long). Origin should go back to at least 2000 B.P. as seen from presence of Caño del Oso complex ceramic, previously dated to at least Neo-Indian Period II (Zucchi, 1965). Coll. 1968 and subm. by Alberta Zucchi, I.V.I.C.

IVIC-457. La Calzada A-1, 5.75 to $6.00 \mathrm{~m}$

$1640 \pm 90$ A.D. 310 
IVIC-476. La Calzada A-1, 7.25 to $7.50 \mathrm{~m}$

IVIC-475. La Calzada A-1, 8.75 to $9.00 \mathrm{~m}$

\section{Charcoal samples from Trench A, Pit 1 . Assoc.} complex pottery. Dates in agreement with those previously obtained for this ceramic. Comment (A.Z.): dates follow stratigraphic sequence of mound. IVIC-475 comes from one of deepest levels and could represent initiation of structure.

\section{IVIC-470. La Calzada B-1, $1.00 \mathrm{~m}$, wood}

IVIC-469. La Calzada B-1, 2.00 to $2.25 \mathrm{~m}$

IVIC-452. La Calzada B-1, 4.75 to $5.00 \mathrm{~m}$

IVIC-472. La Calzada B-1, 7.75 to $8.00 \mathrm{~m}$
Modern

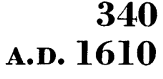

$1670 \pm 100$ A.D. 280

$$
1800 \pm 100
$$

A.D. 150
$340 \pm 60$

Charcoal and one wood (IVIC-470) samples from Trench B, Pit 1. Caño del Oso complex ceramics assoc. with these specimens. The wood of IVIC-470 was well preserved and modern date confirms suspicion that it is intrusive. IVIC-469 consisted of very small fragments of charcoal. Carbon was extracted by combustion of sample with assoc. earth since physical separation was not practical. Due to minimal size of particles, natural intrusion by action of infiltrating water cannot be excluded. Therefore, IVIC-470 and IVIC-469 are considered as not necessarily representing ages of ceramics recovered at these levels. Comment (A.Z.): IVIC452 and IVIC-472 correlated with previous series and are in agreement with stratigraphy.

\section{IVIC-459. La Calzada B-2, 2.25 to $2.50 \mathrm{~m}$}

$$
\begin{array}{r}
1560 \pm 70 \\
\text { A.D. } 390 \\
1410 \\
\text { A.D. } 540 \\
1510 \\
150 \\
\text { A.D. } 440
\end{array}
$$$$
\text { IVIC-454. La Calzada B-2, } 3.25 \text { to } 3.50 \mathrm{~m}
$$

IVIC-471. La Calzada B-2, 8.50 to $8.75 \mathrm{~m}$

Charcoal samples from Trench B, Pit 2 Caño del Oso complex pottery found at all levels. Comment (A.Z.): IVIC-459 and IVIC-454 are reasonable. IVIC-471 appears a little too recent; however, details of stratigraphic characteristics have not yet been studied.

\section{IVIC-474. La Calzada B-6, 9.50 to $9.75 \mathrm{~m} \quad$ A.D. 250}

Charcoal from Trench B, Pit 6. Assoc. with Caño del Oso complex ceramics. Comment (A.Z.): date reasonable. 
IVIC-460. La Calzada AB-4, 8.00 to $8.25 \mathrm{~m}$

$$
1760 \pm 90
$$

Charcoal from Trenches $\mathrm{A}$ and $\mathrm{B}$, Pit 4. Assoc. with Caño del Oso complex ceramics. Comment (A.Z.): this sample correlates with IVIC-472 and dates agree.

IVIC-436. La Calzada B-11, 11.50 to $11.75 \mathrm{~m}$

$$
\begin{array}{r}
1760 \pm 80 \\
\text { A.D. } 190
\end{array}
$$

IVIC-437. La Calzada B-11, 12.00 to $12.25 \mathrm{~m}$

$1710 \pm 70$

Charcoal samples from Trench B, Pit. 11. Assoc. with Caño del Oso complex ceramics. Comment (A.Z.): in agreement with structure of mound.

\section{IVIC-123-A. La Betania S II, organic carbon}

$$
\begin{array}{r}
\mathbf{8 4 0} \pm \mathbf{8 0} \\
\text { A.D. } 1110 \\
980 \pm 70 \\
\text { A.D. } 970
\end{array}
$$

IVIC-123-B. La Betania S II, carbonate carbon

Small animal bones from Pit S II, 0.50 to $0.75 \mathrm{~m}$ below surface of La Betania site, state of Barinas, Venezuela $\left(8^{\circ} 12^{\prime} \mathrm{N}\right.$ Lat, $70^{\circ} 5^{\prime} \mathrm{W}$ Long). Assoc. with Caño del Oso ceramics dated previously (Tamers, 1965) ai ca. 1750 B.P. Coll. 1964 and subm. by Alberta Zucchi. Fluorine content was measured at $0.2 \%$. Organic carbon content was only $0.4 \%$ and carbonate carbon $0.5 \%$. Comment: fluorine analysis is better indication of age than organic carbon content, which could suggest much greater antiquity. Radiocarbon dates are too recent, in agreement with previous studies on known-age bones (Tamers and Pearson, 1965).

\section{IVIC-418. Necuima $1,0.10$ to $0.20 \mathrm{~m}$}

A.D. 1350

$600 \pm 80$

\section{IVIC-417. Necuima $1,0.20$ to $0.30 \mathrm{~m}$}

$$
2030 \pm 70
$$

80 в.c.

Charcoal samples from Canyon of Necuima, Bajo Caroní, state of Guayana, Venezuela $\left(7^{\circ} 49^{\prime} \mathrm{N}\right.$ Lat, $62^{\circ} 59^{\prime} \mathrm{W}$ Long). Excavation ca. $800 \mathrm{~m}$ NE Presa Guri dike on Hill 1, Trench 1, Sec. 40. Artifacts include abundant ceramic fragments and worked stones, with major portions in upper level. These are the 1 st $\mathrm{C}^{14}$ dates for Guayana region. Coll. 1967 and subm. by Jorge Armand, Mus. of Natural Sci., Caracas, Venezuela. Comment (J.A.): artifacts' style has not been previously encountered, but 2030 в.P. date is entirely possible; 600 B.P. date could be due to mixture with modern material from surface.

\section{Paleo-Indian Epoch}

\section{IVIC-488. Muaco bones}

$9030 \pm 240$

7080 B.c.

Bones, some charred, from extinct animals taken $0.85 \mathrm{~m}$ below surface, F-H square, of Muaco site, state of Falcón, Venezuela $\left(11^{\circ} 45^{\prime} \mathrm{N}\right.$ Lat, $69^{\circ} 15^{\prime} \mathrm{W}$ Long). Assoc. with stone artifacts (Rouse and Cruxent, 1963b). 
Coll. 1959 and subm. by José Cruxent. Fluorine content of these bones was $1.1 \%$, in agreement with their age. Radiocarbon dating pretreatment included dissolving in hydrochloric acid, which insured complete removal of large concentrations of carbonates; $0.36 \%$ organic carbon. Previous date for site was 14,300 \pm 500 B.P. (M-1068, Radiocarbon, 1962, v. 4, p. 200) from $1.85 \mathrm{~m}$ below surface. Comment (J.C.): 9030 B.P. date is more reasonable for artifacts. Taima-taima (Cruxent, 1967), dated at 13,010 士 280 and 14,440 \pm 435 в.P. (IVIC-191-1 and IVIC-191-2, Radiocarbon, 1966 , v. 8, p. 206) should be older than Muaco. It would be unexpected that these 2 cultures could have existed at same period.

\section{IVIC-191-B. Taima-taima carbonates \\ 5640 B.C.}

$7590 \pm 100$

Carbonate portion of bones from extinct animals of kill site in state of Falcón, Venezuela (11 $1^{\circ} 30^{\prime} \mathrm{N}$ Lat, 69 $30^{\prime} \mathrm{W}$ Long) (Cruxent, 1967). Organic fraction was previously dated at 13,010 \pm 280 and 14,440 上 435 B.P. (IVIC-191-1 and IVIC-191-2, op. cit., above). Measurement made in order to observe extent of carbonate portion errors for use in interpretation of following samples. Previous study (Tamers and Pearson, 1965) showed carbonate portion dates $3000 \mathrm{yr}$ too young on known age bones $10,000 \mathrm{yr}$ old. These Traima-taima bones consist of $0.5 \%$ organic carbon and $1.7 \%$ carbonate carbon. Fluorine content was 1.0\%. Coll. 1963 and subm. by José Cruxent. Comment: carbonate carbon date is 6000 to 7000 $\mathrm{yr}$ more recent than organic carbon result. Fluorine content indicates Pleistocene origin.

\section{IVIC-511-B. Cucuruchú 108}

$5860 \pm 80$ 3910 B.C.

Carbonate portion of fossilized megathere bones from Hacienda Cucuruchú, La Vela municipality, state of Falcón, Venezuela $\left(11^{\circ} 30^{\prime} \mathrm{N}\right.$ Lat, $69^{\circ} 30^{\prime} \mathrm{W}$ Long). Assoc. with Paleo-Indian stone lance point. Coll. 1968 and subm. by José Cruxent. Bones contained only $0.04 \%$ organic carbon, which precluded dating this portion. The $1.3 \%$ carbonate carbon content was sufficient and comparing with previous Taima-taima carbonate date, an age estimation could be made. Fluorine content was $1.4 \%$. Comment: fluorine measurement agrees with Pleistocene origin suggested by radiocarbon.

\section{IVIC-512-B. Cucuruchú 104}

$\mathbf{3 9 8 0} \pm \mathbf{7 0}$ 2030 B.c.

Carbonate portion of fossilized glyptodont bones from same site as IVIC-511-B (11 ${ }^{\circ} 30^{\prime} \mathrm{N}$ Lat, 69 $30^{\prime} \mathrm{W}$ Long); however this sample could be more recent. Organic carbon content was $0.06 \%$ and carbonate carbon $2.3 \%$. Bones contained 2.0\% fluorine. Coll. 1968 and subm. by José Cruxent. Comment: fluorine content indicates Pleistocene age, not more recent than IVIC-511. Radiocarbon date on carbonate disagrees.

\section{IVIC-514-A. Cucuruchú 103, organic carbon}




\section{IVIC-514-B. Cucuruchú 103, carbonate carbon 1400 B.c.}

Fossilized tortoise shell from same site as IVIC-511-B $\left(11^{\circ} 30^{\prime} \mathrm{N}\right.$ Lat, $69^{\circ} 30^{\prime} \mathrm{W}$ Long). Organic carbon content was $0.3 \%$ and carbonate carbon $4 \%$, which permitted analyses of both fractions. Bones contained $0.6 \%$ fluorine. Coll. 1968 and subm. by José Cruxent, who suspected that this sample was younger than IVIC-511-B. Comment: fluorine content and organic carbon date indicate early Holocene origin.

\section{IVIC-513-B. La Maraquita}

$8980 \pm 120$

Carbonate portion of fossilized Upper Pleistocene animal bones from Quebrada de Maraquita, J. B. Rodriguez municipality, state of Lara, Venezuela $\left(9^{\circ} 50^{\prime} \mathrm{N}\right.$ Lat, $69^{\circ} 40^{\prime} \mathrm{W}$ Long). Organic carbon content was $0.05 \%$ and carbonate carbon $2.7 \%$. Bones contained $1.5 \%$ fluorine. Coll. 1968 by Adrian Lucena, Univ. Central, Caracas and subm. by José Cruxent. Comment: fluorine content in agreement with Pleistocene origin.

\section{IVIC-515-B. El Palomo}

$5800 \pm 80$

Carbonate portion of fossilized bones, presumably Upper Pleistocene, from Cerro Palomo site, Quibor municipality, state of Lara, Venezuela $\left(9^{\circ} 50^{\prime} \mathrm{N}\right.$ Lat, $69^{\circ} 40^{\prime} \mathrm{W}$ Long). Organic carbon content was $0.3 \%$ and carbonate carbon $2.1 \%$. Bones contained $0.3 \%$ fluorine. Coll. 1968 by Adrian Lucena and subm. by José Cruxent. Comment: fluorine content suggests early Holocene origin.

\section{IVIC-486-A. Montalbán}

Modern

Human bones taken just below surface in Montalbán, El Paraíso sec. of Caracas $\left(10^{\circ} 29^{\prime} \mathrm{N}\right.$ Lat, $66^{\circ} 56^{\prime} \mathrm{W}$ Long). Acid dissolving pretreatment used to eliminate carbonate. Organic carbon content was $2.6 \%$. Located at site in which was excavated a skull with allegedly primitive traits. Fluorine content was $0.15 \%$ and that of skull $0.25 \%$. Coll. 1968 and subm. by Leopoldo Osio Mariño, Policía Técnica Judicial, Caracas. Comment: skull would not be sacrificed for radiocarbon analysis. Similarity of fluorine contents, however, indicates that it has approx. same age as Montalbán bones and is, therefore, not old enough to have been primitive species of man.

\section{IVIC-319. Rio Nuevo B-C-19}

\section{B. Jamaica}

Charcoal from $\mathrm{N}$ coast of Jamaica, Ocho Rios region, on elev. area of Rio Nuevo ( $18^{\circ} 22^{\prime} \mathrm{N}$ Lat, $77^{\circ} 5^{\prime} \mathrm{W}$ Long). From Trench 19, $\mathrm{N}$ sec. 0.00 to $0.25 \mathrm{~m}$ below surface. A Mexican-Spanish complex, this site was fortified by last Spanish governor, Isasi. Estimated date, A.D. 1655. Coll. 1965 and subm. by José Cruxent. Comment: radiocarbon content is not in disagreement with submitter's date estimation because known-age 
samples from this period falsely appear $<100 \mathrm{yr}$ old (Broecker, Olson, and Bird, 1959).

\section{Chile}

\section{IVIC-344. Conanoxa 480}

Llama wool cloth from Tomb 1 of Túmulos cemetery in Conanoxa E site, Camarones Valley, Tarapacá Province, Chile $\left(19^{\circ} 2^{\prime} \mathrm{S}\right.$ Lat, $69^{\circ} 59^{\prime}$ W Long). Attributed to the Agrícola Temprano period of N Chile, which was thought to extend from 0 to A.D. 700 (Niemeyer and Schiappacasse, 1963). Early culture from this site was dated at $1150 \pm 95$ B.P. (IVIC-176, Radiocarbon, 1966 , v. 8 , p. 209) and a later pre-agriculture complex at $3740 \pm 130$ (IVIC-175, op. cit., above, p. 208). Coll. 1961 and subm. by Hans Niemeyer and Virgilio Schiapacasse, Santiago, Chile. Comment (H.N. and V.S.): this date shows that Agrícola Temprano period began earlier than was previously suspected.

\section{IVIC-331. Guanaqueros 3}

$3330 \pm 110$ 1380 B.C.

Sea wolf (Otaria) bones from excavation over marine terrace +5 to $+7 \mathrm{~m}$ above Bay of Guanagueros, Cioquimbo Province, Chile $\left(30^{\circ} 10^{\prime} \mathrm{S}\right.$ Lat, $72^{\circ} 25^{\prime} \mathrm{W}$ Long). Located in Pit 7, 2nd cultural level which should be more recent than IVIC-342. Assoc. with bone harpoons and fish hooks as well as grinding and perforated stones. Coll. 1963 and subm. by Hans Niemeyer and Virgilio Schiappacasse. Bones received pretreatment that completely removed carbonates. Organic carbon content was $2.3 \%$. Comment (H.N. and V.S.): this conchal belongs to preceramic society of fishers and collectors (Schiappacasse and Niemeyer, 1964). Date places occupation during Sub-Boreal thermal oscillation.

\section{IVIC-342. Guanaqueros 1 and 2}

$3760 \pm 110$

Charred human and animal bones of Pit $7,1.47$ and $1.60 \mathrm{~m}$ below surface of same site as IVIC-331 $\left(30^{\circ} 10^{\prime} \mathrm{S}\right.$ Lat, $72^{\circ} 25^{\prime} \mathrm{W}$ Long). Assoc. with harpoon points and human bones painted with ochre pigment. Culture different from that of IVIC-391. Coll. 1963 and subm. by Hans Niemeyer and Virgilio Schiappacasse. Bones treated with hydrochloric acid to remove carbonates. Organic carbon content was $1.2 \%$. Comment (H.N. and V.S.): this sample being encountered at level lower than that of IVIC-331, older date was expected.

\section{IVIC-164. ENAP 3A}

Modern

Small charcoal sample from excavation in ENAP refinery near mout' of Aconcagua R., Concon, Valparaíso Prov., Chile ( $32^{\circ} 56^{\prime} \mathrm{S}$ Lat, $71^{\circ} 32^{\prime}$ W Long). From Sq. a-12, Stratum IV, Level c of shell mound, with ceramic artifacts and burials. Should date agricultural group of central coast of Chile. Coll. 1963 and subm. Bernardo by Berdichevsky Scher, Univ. de Chile, Santiago. Age estimated as ca. 1000 B.P. (Berdichevsky, 1963). 
IVIC-165. ENAP 3B

Modern

Small charcoal sample from same site as IVIC-165. In Sq. g-12, ca. $1.60 \mathrm{~m}$ below surface. Should date formative culture with ceramics. Estimated age 1500 в.P.

\section{IVIC-238. Kaiser 7}

\section{Curacao}

Charcoal from Pit $7,0.00$ to $0.25 \mathrm{~m}$ below surface of excavation on top of Meiber hill, SW Landhuis Engels, Curacao $\left(12^{\circ} 12^{\prime} \mathrm{N}\right.$ Lat, $69^{\circ} 15^{\prime}$ W Long). Early Dutch settlement estimated to date A.D. 1550 to 1675 . However, there exist some mines that could be Spanish or primitive Dutch settlement of 1st half of 16th century. Various types of majolica found coincide with those of Gaito, dated at A.s. 1610 (IVIC-241, Radiocarbon, 1967, v. 9, p. 243). Coll. 1965 and subm. by José Cruxent. Comment: see IVIC-243.

IVIC-243. Kaiser 6

Modern

Charcoal from Pit $6,0.00$ to $0.25 \mathrm{~m}$ below surface adjacent to excavation of IVIC-238 (12 $12^{\prime} \mathrm{N}$ Lat, $69^{\circ} 15^{\prime} \mathrm{W}$ Long). Same types of artifacts as previous sample. Estimated date, A.D. 1700 to 1850. Coll. 1965 and subm. by José Cruxent. Comment: modern dates suggest that both samples originated after A.D. 1670 and probably before A.D. 1770. Therefore, radiocarbon contents are in agreement with submitter's estimations and exclude 16th century possibility for IVIC-238.

\section{E. Dominican Republic}

\section{IVIC-4.22. La Caleta}

$670 \pm 70$

Charcoal from 0.36 and $0.96 \mathrm{~m}$ below surface from excavation in La Caleta, Natl. Dist., Dominican Republic (18 $27^{\prime} \mathrm{N}$ Lat, $69^{\circ} 41^{\prime} \mathrm{W}$ Long). Assoc. with new ceramic style. Coll. 1966 by Morban Laucer, Univ. Autónoma, Santo Domingo, and subm. by José Cruxent.

\section{IVIC-483. Cueva de Los Paredones}

Unidentified earth material (peat?) containing ca. $3 \%$ non-carbonate carbon taken $0.4 \mathrm{~m}$ below surface in cave $\mathrm{E}$ of Santo Domingo, Dominican Republic (18 $27^{\prime} \mathrm{N}$ Lat, $69^{\circ} 41^{\prime} \mathrm{W}$ Long). Statutes carved from stalagmites found in cave belonging to unknown complex. Sample assoc. with badly calcified bones whose organic carbon content was only $0.014 \%$, lowest value we have seen for unburned bones. Fluorine content of bones was $0.15 \%$. Coll. 1968 and subm. by José Cruxent, who estimated age of complex at ca. 1000 yr. Comment: peat does not date culture. Bones, however, have fluorine content that agrees with submitter's age estimation.

\section{F. Argentina}

IVIC-266. Palo Blanco 7

$3820 \pm 80$

1870 B.C.

Mollusk shells from natural formation at Palo Blanco, Prov. of Buenos Aires, Argentina (34 $55^{\prime} \mathrm{S}$ Lat, $57^{\circ} 50^{\prime} \mathrm{W}$ Long). Taken $0.70 \mathrm{~m}$ 
below surface. Base of this mound was previously dated at $4760 \pm 120$ B.P. (IVIC-188, Radiocarbon, 1966, v. 8, p. 211) and it was expected that upper level would be younger. Marine shells are probably younger than radiocarbon analysis indicates and errors varying from 0 to $700 \mathrm{yr}$ have been observed (Taylor and Berger, 1967). Therefore, radiocarbon content difference between IVIC-188 and this sample does not give unambiguous interpretation. Coll. 1965 and subm. by Eduardo Cigliano, Mus. de La Plata, La Plata, Argentina.

\section{IVIC-270. Punta del Indio}

$5880 \pm 80$

Mollusk shells from formation similar to that of IVIC-266, excavated in Punta del Indio, Magdalena, Prov. of Buenos Aires, Argentina $\left(35^{\circ} 10^{\prime}\right.$ $\mathrm{S}$ Lat, $57^{\circ} 15^{\prime} \mathrm{W}$ Long), $0.60 \mathrm{~m}$ below surface. Coll. 1965 and subm. by Eduardo Cigliano, who estimated age to be same as IVIC-188. Comment: from observed variations in known age marine shells (Taylor and Berger, 1967), it is possible that this sample and IVIC-188 are contemporary; however, it is unlikely that radiocarbon age difference between IVIC270 and IVIC-266 is not real.

\section{G. Mexico}

$$
1230 \pm 60
$$

\section{IVIC-484. Pyramid Sayil}

A.D. 720

Wood from supporting beam of top portion of "Palace", Sayil, Yucatán, Mexico (20 $0^{\circ} 15^{\prime} \mathrm{N}$ Lat, 89 $33^{\circ} \mathrm{W}$ Long). Coll. 1968 and subm. by Karl Gaede, I.V.I.C. Comment: date places structure in N Maya area Florescent period, 1st phase.

\section{IVIC-485. Uxmal}

$$
1210 \pm 60
$$

Wood from portal of small structure directly behind pyramid "La Divina” in Uxmal, Yucatán, Mexico (20 20 $0^{\prime} \mathrm{N}$ Lat, $89^{\circ} 47^{\prime} \mathrm{W}$ Long). Other clates for this site are $1390 \pm 50$ в.P. (Y-627, Radiocarbon, 1959, v. 1, p. 165) for La Divina pyramid and $1065 \pm 100$ B.P. (Gro-613, Science, 1958, v. 127, p. 136) for Monjas Quadrangle. Coll. 1968 and subm. by Karl Gaede. Comment: in agreement with previous dates. N Maya Florescent period, 1st phase.

\section{H. United States}

\section{IVIC-200. Newberry Crater, Oregon}

$$
\begin{array}{r}
1330 \pm 60 \\
\text { A.D. } 620
\end{array}
$$

Charcoal from caldera of Newberry volcano $\left(43^{\circ} 43^{\prime} \mathrm{N}\right.$ Lat, $121^{\circ} 15^{\prime}$ W Long), Oregon. Found beneath uppermost pumice layer. Coll. 1964 by U. S. Clanton, NASA Manned Spacecraft Center, Houston, Texas and subm. by E. Mott Davis, Univ. of Texas, as check sample. Previous date was $1270 \pm 60$ B.P. (Tx-245, Radiocarbon, 1966, v. 8, p. 459). Comment: in agreement with Univ. of Texas measurement.

\section{ETHNOLOGIC SAMPLES}

There are presently ca. 70,000 Indians living in tribal complexes in interior of Venezuela. These groups are subjects of ethnologic studies 
carried out by researchers of several nations. The Warao, inhabiting the Delta Amacuro swamps, of difficult accessibility, are under intense observation in this inst. (Suárez, 1968; Layrisse and Wilbert, 1966). These Indians were used for investigation of application of recent radiocarbon contamination as a control in ethnology. Radiocarbon increase in Venezuela is known during the past decade (see sec. IV) and estimates of ages of Indian shelters are controlled for reasonability compared with radiocarbon contents of the Temiche (Manicaria saccifera) palm leaves used for roofs. Actual datings are not possible due to peaks in contemporary radiocarbon curve. This means that specific values will be typical of more than $1 \mathrm{yr}$. In most cases samples were taken from opposite sides of the roofs and individually measured to reduce possibility of abnormal fluctuation in atmosphere giving a false indication.

Of principal interest was ability of the Indians to think in the past. General procedure was to assemble occupants of camps by means of cigarette and candy distributions and to initiate, with assistance of the guide-interpreter, a discussion of when each structure of interest was built. Passage of a yr is clearly seen by the Indians due to seasonal distribution of rainfall. The Warao language has a perfectly developed counting system continuing at least into the thousands (Vaquero, 1965).

Samples coll. July, 1966 and subm. by members of the Radiocarbon Lab. Detailed discussion of this investigation, especially that of Hoana and Iburunia camps, will be publ. elsewhere (Tamers, 1969).

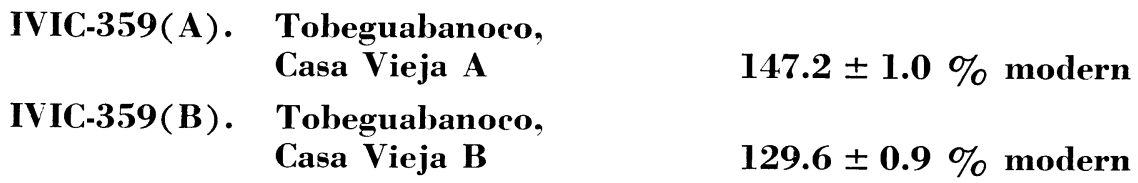

From oldest house in Tobeguabanoco camp $\left(9^{\circ} 1^{\prime} \mathrm{N}\right.$ Lat, $61^{\circ} 0^{\prime} \mathrm{W}$ Long). Same site as known age sample IVIC-358. Indians calculated structure as $4 \mathrm{yr}$ old, i.e., built in 1962, and claimed it to predate, by a few months, IVIC-358, known to have been constructed in 1962. Comment: radiocarbon contents would suggest 1963 as being more reasonable.

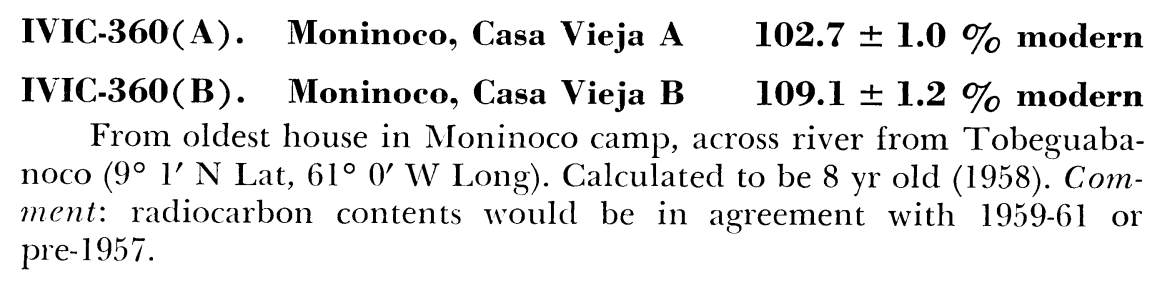

\section{Hoana camp}

This group of Warao (9० $2^{\prime} \mathrm{N}$ Lat, $60^{\circ} 58^{\prime} \mathrm{W}$ Long) has been studied intensively (Suárez, 1968). Order of construction was of interest for comparison with lineage of this family. The Indians were questioned first with aid of guide and again 2 weeks later without his help and prompting. Detailed description of this camp will be publ. elsewhere (Tamers, 1969). 
IVIC-362(A). Hoana, Casa Vieja A

$120.5 \pm 0.9 \%$ modern

IVIC-362(B). Hoana, Casa Vieja B

$119.1 \pm 0.7 \%$ modern

Chief's house, oldest and largest in camp. First report gave construction date as 1960, 2nd report as 1962. Comment: in agreement with 1962.

IVIC-377(A). Hoana, Casa 2 A

$114.6 \pm 1.0 \%$ modern

IVIC-377(B). Hoana, Casa 2 B

$119.8 \pm 0.8 \%$ modern

First report stated this to be 2nd construction in camp and dated at 1962. Second report gave this as 3rd construction, no specific date. Comment: radiocarbon in agreement with construction in 1962-63. Could be 2nd, 3rd, or 4th house.

$\begin{array}{lll}\text { IVIC-378(A). } & \text { Hoana, Casa } 3 \text { A } & 118.7 \pm 0.9 \% \text { modern } \\ \text { IVIC-378(B). } & \text { Hoana, Casa } 3 \text { B } & 127.7 \pm 0.9 \% \text { modern }\end{array}$

First report stated this to be 3rd construction and dated same time as IVIC-377. Second report claimed house as 4 th. Comment: radiocarbon in agreement with Indians' estimations.

$\begin{array}{llll}\text { IVIC-379(A). } & \text { Hoana, Casa 4 A } & 120.5 \pm 0.7 \% \text { modern } \\ \text { IVIC-379(B). } & \text { Hoana, Casa 4 B } & 119.3 \pm 0.7 \% \text { modern }\end{array}$

First report stated this to be 4th construction and dated same time as IVIC-377 and IVIC-378. Second report claimed house to be 6th constructed. Comment: radiocarbon in agreement with 1 st report, but not with 2nd. This shelter probably predates those of IVIC-380 and IVIC-382.

$\begin{array}{lll}\text { IVIC-380(A). } & \text { Hoana, Casa } 5 \text { A } & 144.3 \pm 0.9 \% \text { modern } \\ \text { IVIC-380(B). } & \text { Hoana, Casa } 5 \text { B } & 121.7 \pm 1.9 \% \text { modern }\end{array}$

First report stated this to be 5th construction and dated at 1963. Second report gave this as 2 nd house, no specific date. Comment: radiocarbon suggests construction in late 1963 or early 1964. In disagreement with 2nd report.

$\begin{array}{lll}\text { IVIC-381(A). } & \text { Hoana, Casa } 6 \text { A } & 141.0 \pm 0.7 \% \text { modern } \\ \text { IVIC-381(B). } & \text { Hoana, Casa } 6 \text { B } & 140.4 \pm 0.9 \% \text { modern }\end{array}$

First report gave this shelter as 6th and dated 1964-65. Second report placed this as 7 th, no specific date. Comment: radiocarbon suggests construction in late 1963 or early 1964.

$\begin{array}{llll}\text { IVIC-382(A). } & \text { Hoana, Casa } 7 \text { A } & 141.3 \pm 0.7 \% \text { modern } \\ \text { IVIC-382(B). } & \text { Hoana, Casa } 7 \text { B } & 158.2 \pm 1.0 \% \text { modern }\end{array}$

Given as 7 th construction in 1st report and dated at 1965 . Second report claimed this as 5 th house, no specific date. Comment: radiocarbon suggests early 1964, due to relatively low value of IVIC-382(A).

IVIC-383(A). Hoana, Casa 8 A $\quad 158.1 \pm 1.0 \%$ modern 
IVIC-383(B). Hoana, Casa 8 B

$154.7 \pm 1.5 \%$ modern

Claimed to be latest construction in both 1st and 2nd reports and dated as only 1 yr old (1965). Comment: radiocarbon contents agree with Indians' estimation.

IVIC-364(A). Jobure, Casa Vieja A $108.2 \pm 1.1 \%$ modern

IVIC-364(B). Jobure, Casa Vieja B

$107.4 \pm 1.2 \%$ modern

Oldest house in Jobure camp $\left(8^{\circ} 58^{\prime} \mathrm{N}\right.$ Lat, $61^{\circ} 0^{\prime} \mathrm{W}$ Long). Same site as IVIC-363. Date calculated to be either 1953-54 or 1951. Commen : radiocarbon contents suggest post-1952.

\section{IVIC-365(A). Mariusa, Casa Vieja A $\quad 124.1 \pm 1.3 \%$ modern \\ IVIC-365(B). Mariusa, Casa Vieja B $122.3 \pm 0.9 \%$ modern}

Oldest house in Mariusa camp $\left(9^{\circ} 14^{\prime} \mathrm{N}\right.$ Lat, $61^{\circ} 6^{\prime} \mathrm{W}$ Long), most removed from missionary influence of the Warao. Age calculated as 8 yr old (1958). Comment: radiocarbon contents not in disagreement with the Indians' estimate.

\section{IVIC-371(A). Araguao, Casa Vieja A $131.7 \pm 1.1 \%$ modern \\ IVIC-371(B). Araguao, Casa Vieja B $127.8 \pm 1.3 \%$ modern}

Oldest house in Araguao camp, on Caño Araguao $\left(9^{\circ} 8^{\prime} \mathrm{N}\right.$ Lat, $61^{\circ}$ $6^{\prime} \mathrm{W}$ Long). Although camp rather large, chief insisted that his people arrived here only 4 yr ago (1962). Comment: radiocarbon contents in agreement with 1962.

\section{IVIC-373(A). Güinigüina, Casa Vieja A $119.4 \pm 0.9 \%$ modern}

IVIC-373(B). Güinigüina, Casa Vieja B $116.7 \pm 0.9 \%$ modern

Oldest structure in Güinigüina camp $\left(9^{\circ} 16^{\prime} \mathrm{N}\right.$ Lat, $61^{\circ} 5^{\prime} \mathrm{W}$ Long). Difference of opinion between Indians that estimated house to be 5 yr old (1961) or 9 yr old (1957). Comment: radiocarbon contents not in agreement with 1961; however, 1957 would be reasonable.

IVIC-374(A). Arabaruici, Casa Vieja A $132.7 \pm 0.9 \%$ modern

IVIC-374(B). Arabaruici, Casa Vieja B $137.4 \pm 0.9 \%$ modern

Oldest house in Arabaruici camp, Caño Güinigüina, almost adjacent to Renault Sawmill $\left(9^{\circ} 12^{\prime} \mathrm{N}\right.$ Lat, $61^{\circ} 5^{\prime} \mathrm{W}$ Long). Estimated date 1962. Comment: radiocarbon contents suggest late 1963. IVIC-375(A). Boca Mojavaina,
Casa Vieja A $132.6 \pm 1.1 \%$ modern

IVIC-375(B). Boca Mojavaina, Casa Vieja B

$138.2 \pm 1.4 \%$ modern

Oldest house in Boca Mojavaina camp $\left(9^{\circ} 11^{\prime} \mathrm{N}\right.$ Lat, $61^{\circ} 7^{\prime} \mathrm{W}$ Long). General discussion placed structure as 3 yr old (1963). Comment: radiocarbon contents agree with late 1963. 
IVIC-376(A). Ataicida, Casa Vieja A

$115.1 \pm 0.8 \%$ modern

IVIC-376(B). Ataicida, Casa Vieja B

$132.1 \pm 0.9 \%$ modern

Oldest house in Ataicida camp $\left(9^{\circ}-1^{\prime} \mathrm{N}\right.$ Lat, $61^{\circ} 1^{\prime} \mathrm{W}$ Long). Estimated construction in 1962. Comment: radiocarbon contents agree with Indians' estimate.

IVIC-389. Casa del Francés

$100.5 \pm 0.8 \%$ modern

Claimed to be oldest house in village of Curiapo $\left(8^{\circ} 32^{\prime} \mathrm{N}\right.$ Lat, $61^{\circ}$ $0^{\prime} \mathrm{W}$ Long). Temiche roof still in good condition and should be more than $15 \mathrm{yr}$ old (1951). Comment: radiocarbon contents show pre-thermonuclear testing age, i.e., before 1952 .

\section{Aneceto camp}

This settlement $\left(8^{\circ} 42^{\prime} \mathrm{N}\right.$ Lat, $60^{\circ} 47^{\prime} \mathrm{W}$ Long) located near village of Curiapo and has extensive contacts with Criollos. Indians stated that all shelters were constructed the same year, 1962.

$\begin{array}{llll}\text { IVIC-390(A). } & \text { Aneceto } 1 & \text { A } \\ \text { IVIC-390(B). } & \text { Aneceto } 1 & \text { B } \\ \text { IVIC-391(A). } & \text { Aneceto } 2 & \text { A } \\ \text { IVIC-391(B). } & \text { Aneceto } 2 & \text { B } \\ \text { IVIC-392(A). } & \text { Aneceto } 3 & \text { A } \\ \text { IVIC-392(B). } & \text { Aneceto } 3 & \text { B } \\ \text { IVIC-393(A). } & \text { Aneceto } 4 & \text { A } \\ \text { IVIC-393(B). } & \text { Aneceto } 4 & \text { B } \\ \text { IVIC-394(A). } & \text { Aneceto } 5 & \text { A } \\ \text { IVIC-394(B). } & \text { Aneceto } 5 & \text { B }\end{array}$

$137.7 \pm 1.2 \%$ modern

$134.3 \pm 0.9 \%$ modern

$170.4 \pm 1.1 \%$ modern

$164.6 \pm 1.1 \%$ modern

$170.2 \pm 1.5 \%$ modern

$169.4 \pm 1.1 \%$ modern

$158.4 \pm 1.2 \%$ modern

$159.0 \pm 1.1 \%$ modern

$171.2 \pm 1.1 \%$ modern General Comment: principal structure, IVIC-390, has radiocarbon contents that suggest late 1963 or early 1964 . Other houses were constructed in 1964 or 1965. This is in disagreement with Indians' statement.

\section{Iburunia camp}

The Warao of Iburunia camp ( $8^{\circ} 42^{\prime} \mathrm{N}$ Lat, $60^{\circ} 46^{\prime} \mathrm{W}$ Long) on Caño Uricahamana, have inhabited site for more than $30 \mathrm{yr}$. Original constructions have all been replaced. Present situation shown in detailed description to be publ. elsewhere (Tamers, 1969).

\footnotetext{
IVIC-395(A). Iburunia, Casa Vieja A $122.1 \pm 0.9 \%$ modern

IVIC-395(B). Iburunia, Casa Vieja B $\quad 110.4 \pm 0.8 \%$ modern

Chief's house, oldest in camp. Claimed to have been constructed in 1958. Comment: radiocarbon contents not in disagreement with Indians' estimation.
} 
IVIC-396(A). Iburunia 2 A

$131.0 \pm 0.9 \%$ modern

IVIC-396(B). Iburunia 2 B

142.4 $\pm 0.9 \%$ modern

Claimed to be 2nd oldest house and dated at 1962. Comment: radiocarbon contents in agreement with order, but suggest late 1963 or early 1964.

IVIC-397(A). Iburunia 3 A

$144.0 \pm 0.9 \%$ modern

IVIC-397(B). Iburunia 3 B

$126.1 \pm 1.1 \%$ modern

Claimed to be 3rd oldest house and dated at 1963. Comment: radiocarbon contents agree with late 1963 .

$\begin{array}{lll}\text { IVIC-398(A). } & \text { Iburunia 4 A } & 164.9 \pm 1.0 \% \text { modern } \\ \text { IVIC-398(B). } & \text { Iburunia 4 B } & 151.6 \pm 1.0 \% \text { modern }\end{array}$

Claimed to be 4 th oldest house and dated 1965. Comment: radiocarbon contents agree with 1965, but this structure is more recent than IVIC-399.

$\begin{array}{lll}\text { IVIC-399(A). } & \text { Iburunia } 5 \text { A } & 134.9 \pm 0.9 \% \text { modern } \\ \text { IVIC-399(B). } & \text { Iburunia } 5 \text { B } & 146.0 \pm 0.9 \% \text { modern }\end{array}$

Claimed to be 5th oldest house and dated 1965. Comment: radiocarbon contents suggest late 1963 or early 1964. This shelter predates IVIC-398.

IV. KNOWN-AGE SAMPLES

The observed pattern of atmospheric radiocarbon contamination during the past decade in Venezuela differs from that measured in the temperate zones (Tamers, 1967b). This is interpreted as principally caused by $\mathrm{CO}_{2}$ exchange with tropical oceans. Recent results on sea water exposure to air support this conclusion (Berger and Libby, 1968). The radiocarbon excesses are being used for the control of age estimations of recent events. Instead of direct $\mathrm{CO}_{2}$ extractions, tree leaves are employed since this is closer to type of unknown age material in which we are interested.

IVIC-401. Hojas de Guama, Dec. 1966

$164.3 \pm 1.0 \%$ modern

IVIC-424. Hojas de Guama, 31 Jan. 1968

$160.9 \pm 1.4 \%$ modern

IVIC-435. Hojas de Guama, 28 March 1968

$163.1 \pm 0.9 \%$ modern

IVIC-438. Hojas de Guama, 29 April 1968

$158.4 \pm 0.9 \%$ modern

IVIC-473. Hojas de Guama, 29 May 1968

$161.0 \pm 1.0 \%$ modern 
IVIC-479. Hojas de Guama, 29 June 1968

$159.3 \pm 1.0 \%$ modern

IVIC-487. Hojas de Guama, 29 July 1968

$164.0 \pm 1.0 \%$ modern

IVIC-505. Hojas de Guama, 29 August 1968

$159.0 \pm 1.1 \%$ modern

IVIC-518. Hojas de Guama, 2 Oct. 1968

$160.0 \pm 1.0 \%$ modern

IVIC-532. Hojas de Guama,

29 Oct. 1968

$158.8 \pm 1.0 \%$ modern

Green leaves from Guama tree (Inga Fastuosa), $14 \mathrm{~km}$ from Caracas in Altos de Pipe (10 $23^{\prime} \mathrm{N}$ Lat, $66^{\circ} \mathrm{W}$ Long). Same tree as used for May measurements in 1964, 1965, 1966 which gave values of $162 \%$ modern, $171 \%$ modern and $156.7 \%$ modern, respectively (Tamers, 1967b). Coll. and subm. by members of Radiocarbon Lab. Comment: radiocarbon excess has been approx. constant in Venezuela since 1964. There is no noticeable tendency for seasonal distributions.

\section{Delta Amacuro series}

During 2nd expedition in Delta Amacuro Terr. for study described in previous section, samples of Temiche palm (Manicaria saccifera) leaves from roofs of known-age structures were obtained to draw curve for radiocarbon contamination in this region during the past years. When feasible, double samples were taken from opposite sides of each house, which, according to construction technique, meant that they came from different trees and were cut ca. 1 or 2 weeks apart. Leaves employed have had approx. I yr of growth. Coll. July 1966 and subm. by members of the Radiocarbon Lab.

IVIC-372. Coberuna Casa Nueva

$170.0 \pm 0.6 \%$ modern

Green Temiche leaves, from house being constructed in Coberuna camp, Caña Güinigüina, Delta Amacuro $\left(9^{\circ} 11^{\prime} \mathrm{N}\right.$ Lat, $61^{\circ} 5^{\prime} \mathrm{W}$ Long). Coll. 8 July 1968; leaves were cut 5 to 6 July, 1968. Comment: see IVIC400 .

IVIC-384. Hoana Casa Nueva

$166.9 \pm 0.6 \%$ modern

Green Temiche leaves, from house being constructed in Hoana camp, Caño Sacupana, Delta Amacuro (9 $9^{\circ} 2^{\prime} \mathrm{N}$ Lat, $60^{\circ} 58^{\prime} \mathrm{W}$ Long). Coll. 10 July 1968; leaves were cut less than 2 days previously. Comment: see IVIC-400.

\section{IVIC-400. Iburunia Casa Nueva $\quad 153.3 \pm 0.6 \%$ modern}

Green Temiche leaves, being used to put wall on house dated as IVIC-395, Iburunia camp, Caño Urichamana $\left(8^{\circ} 42^{\prime} \mathrm{N}\right.$ Lat, $60^{\circ} 46^{\prime} \mathrm{W}$ Long). Coll. 14 July 1968; leaves were cut less than 2 days previously. 
Comment: samples IVIC-372, 384, and 400 were coll. within space of less than 1 week and illustrate degree of fluctuation that can be expected here.

\section{IVIC-369(A). Aserradero Renault A \\ $117.9 \pm 1.2 \%$ modern}

IVIC-369(B). Aserradero Renault B

$124.4 \pm 1.2 \%$ modern

Temiche leaves from large storage building adjacent to saw mill on Caño Güinigüina, Delta Amacuro $\left(9^{\circ} 12^{\prime} \mathrm{N}\right.$ Lat, $61^{\circ} 5^{\prime} \mathrm{W}$ Long). According to present owner, Renault, construction was during lst 3 mos. of 1957. Samples coll. from opposite ends of roof.

\section{IVIC-388. Casa Medina \\ $107.0 \pm 1.5 \%$ modern}

Temiche leaves from front of house of Sr. Medina, Curiapo, Delta Amacuro $\left(8^{\circ} 32^{\prime} \mathrm{N}\right.$ Lat, $61^{\circ} 0^{\prime} \mathrm{W}$ Long). Family calculated that construction was in Feb. 1958.

\section{IVIC-385(A). Aserradero Guayo A $\quad 130.9 \pm 0.7 \%$ modern \\ IVIC-385(B). Aserradero Guayo B $\quad 109.7 \pm 0.7 \%$ modern}

Temiche leaves from storage building adjacent to saw mill owned by Capuchin missionaries of San Francisco de Guayos, Delta Amacuro $\left(9^{\circ} 0^{\prime} \mathrm{N}\right.$ Lat, $60^{\circ} 59^{\prime} \mathrm{W}$ Long). Construction date May 1958 according to foreman, Carlos Rodriquez, and verified with mission records. Comment: large fluctuations in 1958 were also seen in known age plant samples from Germany (Scharpenseel et al., 1968).

\section{IVIC-386(A). Casa Chirinos A $\quad 99.5 \pm 0.8 \%$ modern \\ IVIC-386(B). Casa Chirinos B $\quad 108.1 \pm 1.0 \%$ modern}

Temiche leaves from abandoned house of Sra. Emma de Chirinos in Curiapo, Delta Amacuro ( $8^{\circ} 32^{\prime} \mathrm{N} \mathrm{Lat,} 61^{\circ} 0^{\prime} \mathrm{W}$ Long). Roof renewed Aug. or Sept. 1959, after birth of child, Aidee.

\section{IVIC-387(A). Curiapo Escuela A $\quad 105.7 \pm 0.9 \%$ modern \\ IVIC-387(B). Curiapo Escuela B $\quad 111.1 \pm 0.7 \%$ modern}

Temiche leaves from roof of school house, Nacional Unitaria No. 80, in Curiapo, Delta Amacuro ( $8^{\circ} 32^{\prime} \mathrm{N}$ Lat, $61^{\circ} 0^{\prime} \mathrm{W}$ Long). Renewal of roof was July to Sept. 1960 according to teacher, Gloria Páez.

\section{IVIC-363(A). Jobure Escuela A $\quad 104.5 \pm 0.7 \%$ modern \\ IVIC-363(B). Jobure Escuela B $\quad 108.6 \pm 0.8 \%$ modern \\ Temiche leaves from roof of school house, in Jobure camp, Delta Amacuro $\left(8^{\circ} 58^{\prime} \mathrm{N}\right.$ Lat, $61^{\circ} 0^{\prime} \mathrm{W}$ Long). Built Dec. 1960 by San Francisco de Guayos mission, as reported by Padre Damain, head.}

IVIC-370. Casa Renault

$118.8 \pm 0.8 \%$ modern

Temiche leaves from roof of family house at Renault saw mill, Caño Güinigüina, Delta Amacuro $\left(9^{\circ} 12^{\prime} \mathrm{N}\right.$ Lat, $61^{\circ} 5^{\prime} \mathrm{W}$ Long). Roof re- 
newed between Jan. and Apr. 1962 as reported by Sra. Renault and corraborated by others.

IVIC-358(A). Tobeguabanoco Escuela A $123.4 \pm 0.7 \%$ modern

IVIC-358(B). Tobeguabanoco Escuela B $122.3 \pm 1.4 \%$ modern

Temiche leaves from opposite ends of roof of school house in Tobeguabanoco camp, Delta Amacuro (9॰ $1^{\prime} \mathrm{N}$ Lat, $61^{\circ} 0^{\prime} \mathrm{W}$ Long). Built Aug. 1962 as shown by records in San Francisco de Guayos mission.

\section{IVIC-361(A). Hoana Escuela A $\quad 120.1 \pm 0.7 \%$ modern \\ IVIC-361 $(B)$. Hoana Escuela B $\quad 119.1 \pm 0.8 \%$ modern}

Temiche leaves from roof of school in Hoana camp, Delta Amacuro $\left(9^{\circ} 2^{\prime} \mathrm{N}\right.$ Lat, $60^{\circ} 58^{\prime} \mathrm{W}$ Long). From opposite ends of structure built in early or mid 1963 by San Francisco de Guayos mission.

\section{Bahía El Tablazo series}

$$
\text { v. Geologic SAMPLes }
$$

Top $20 \mathrm{~cm}$ of underwater sediments in El Tablazo Bay at entrance of Maracaibo Lake in W Venezuela. Canal crosses bay permitting shipping in lake. Sedimentation requires extensive dredging operations. Dating of sediments was undertaken to study various possibilities as to their origin. Samples freed of carbonates by acid-washing pretreatment. Organic carbon contents were ca. $0.2 \%$. Coll. 1966-1968 and subm. by members of the Radiocarbon Lab.

\section{IVIC-279. Canal de Maracaibo B}

Clayey mud in canal between Markers $\mathrm{B} 62$ and $\mathrm{B} 61\left(10^{\circ} 45^{\prime} \mathrm{N}\right.$ Lat, $71^{\circ} 34^{\prime} \mathrm{W}$ Long). Sediments ca. $200 \mathrm{~m} \mathrm{NE}$ on side of canal dated previously at $1470 \pm 150$ B.P. (IVIC-278, Radiocarbon, 1967, v. 9, p. 244).

\section{IVIC-496. Canal de Maracaibo C-1}

$$
1830 \pm 60
$$

Clayey mud in canal between Markers T44 and T43 (10 $53^{\prime} \mathrm{N}$ Lat, $71^{\circ} 3 \overline{7}^{\prime}$ W Long).

\section{IVIC-499. Canal de Maracaibo C-4}

$$
1490 \pm 70
$$

Clayey mud in canal almost between Markers T50 and T49 $\left(10^{\circ} 50^{\prime}\right.$ N Lat, $71^{\circ} 37^{\prime} \mathrm{W}$ Long).

\section{IVIC-502. Canal de Maracaibo C-8}

$$
1870 \pm 70
$$

Clayey mud in canal between Markers $\mathrm{B} 57$ and $\mathrm{B} 58\left(10^{\circ} 47^{\prime} \mathrm{N}\right.$ Lat, $71^{\circ} 36^{\prime} \mathrm{W}$ Long).

\section{IVIC-280. Lado del Canal C}

Sediments from canal side ca. $200 \mathrm{~m}$ S IVIC-279 $\left(10^{\circ} 46^{\prime} \mathrm{N}\right.$ Lat, $71^{\circ} 34^{\prime}$ W Long). 
IVIC-497. Lado del Canal C-2

Fine sand with few shells from canal side ca. $200 \mathrm{~m} \mathrm{E}$ IVIC-496 ( $10^{\circ} 53^{\prime} \mathrm{N} \mathrm{Lat}, 71^{\circ} 36^{\prime} \mathrm{W}$ Long).

IVIC-498. Lado del Canal C-3

$2880 \pm 80$

Fine sand with few shells from canal side ca, $200 \mathrm{~m}$ W IVIC-496 ( $10^{\circ} 53^{\prime} \mathrm{N}$ Lat, $71^{\circ} 37^{\prime} \mathrm{W}$ Long).

IVIC-500. Lado del Canal C-5

$3450 \pm 70$ 1500 B.C.

Fine sand with few shells from canal side ca. $200 \mathrm{~m}$ E IVIC-499 ( $10^{\circ} 50^{\prime} \mathrm{N} \mathrm{Lat,} 71^{\circ} 37^{\prime} \mathrm{W}$ Long).

IVIC-501. Lado del Canal C-6

$3590 \pm 80$

Coarse sand with few shells from canal side ca. $200 \mathrm{~m} \mathrm{~W}$ IVIC-499 $\left(10^{\circ} 50^{\prime} \mathrm{N}\right.$ Lat, $71^{\circ} 38^{\prime} \mathrm{W}$ Long).

IVIC-503. Lado del Canal C-7

$4560 \pm 80$

Coarse sand with many shells and stones from canal side ca. 200 NE IVIC-502 (10 $48^{\prime} \mathrm{N}$ Lat, $71^{\circ} 36^{\prime} \mathrm{W}$ Long).

IVIC-504. Lado del Canal C-9

$1950 \pm 70$

Clayey mud from canal side ca. $200 \mathrm{~m}$ SW IVIC-502 (10 $46^{\prime} \mathrm{N}$ Lat, $71^{\circ} 36^{\prime}$ W Long).

IVIC-520. Bahía El Tablazo C-10

A.D. 1070

$880 \pm 60$

Clayey mud from bay, $\mathrm{W}$ of canal $\left(10^{\circ} 57^{\prime} \mathrm{N}\right.$ Lat, $71^{\circ} 40^{\prime} \mathrm{W}$ Long).

\section{IVIC-521. Bahía EI Tablazo C-11}

$990 \pm 60$

Clayey mud from bay, W of canal ( $10^{\circ} 56.5^{\prime} \mathrm{N}$ Lat, $71^{\circ} 39.5^{\prime} \mathrm{W}$ Long).

IVIC-522. Bahía El Tablazo C-12

Modern Long).

Fine sand with few shells, W of canal $\left(10^{\circ} 55^{\prime} \mathrm{N}\right.$ Lat, $71^{\circ} 39^{\prime} \mathrm{W}$

IVIC-523. Bahía EI Tablazo C-13

A.D. 1340

$610 \pm 90$

Fine sand with few shells, W of canal $\left(10^{\circ} 54.5^{\prime} \mathrm{N}\right.$ Lat, $71^{\circ} 38^{\prime} \mathrm{W}$ Long).

IVIC-524. Bahía El Tablazo C-14

Modern Iong).

Fine sand with many shells, E of canal $\left(10^{\circ} 53^{\prime} \mathrm{N}\right.$ Lat, $71^{\circ} 36^{\prime} \mathrm{W}$

IVIC-525. Bahía El Tablazo C-15

$620 \pm 80$

Fine sand with many shells, $\mathrm{E}$ of canal $\left(10^{\circ} 54^{\prime} \mathrm{N}\right.$ Lat, $71^{\circ} 34.5^{\prime} \mathrm{W}$ Long). 
IVIC-526. Bahía El Tablazo C-16

Modern

Fine sand with few shells, E of canal ( $10^{\circ} 55^{\prime} \mathrm{N}$ Lat, $71^{\circ} 35^{\prime} \mathrm{W}$ Long).

IVIC-527. Bahía El Tablazo C-17

Modern Long).

Fine sand with few shells, $\mathrm{E}$ of canal $\left(10^{\circ} 56.5^{\prime} \mathrm{N}\right.$ Lat, $71^{\circ} 33^{\prime} \mathrm{W}$

IVIC-528. Bahía EI Tablazo C-18

$1020 \pm 60$

Clayey mud, $\mathrm{E}$ of canal $\left(10^{\circ} 58^{\prime} \mathrm{N}\right.$ Lat, $71^{\circ} 34^{\prime} \mathrm{W}$ Long).

IVIC-529. Bahía El Tablazo C-19

$1530 \pm 70$

General Comment: sediments on sides of canal average 2440 B.P. and show greatest variations in ages. Canal sediments are nearly as old and average 1880 B.P., with small variations. Samples from bay are much younger (except for IVIC-529 which is on shore of Zapara Is.) and average 460 B.P. without IVIC-529. These results would agree with hypothesis that most of sedimentation in canal is due to sliding in of sides. Smaller portion comes from natural sedimentation present in rest of bay.

\section{IVIC-531. Punta Guerrero}

Shells (Donax sp.) from fossil beach at Punta Guerrero, Paez dist., state of Zulia, Venezuela ( $11^{\circ} 0^{\prime} 40^{\prime \prime} \mathrm{N}$ Lat, $71^{\circ} 46^{\prime} 35^{\prime \prime} \mathrm{W}$ Long). Taken $2 \mathrm{~m}$ below surface. Importance in determination of movement of Oca fault. Estimated age either Holocene or late Pleistocene. Coll. 1968 by Lloyd C. Cluff and subm. by J. M. Bowen, Compañía Shell de Venezuela. Comment (J.M.B.): reasonable, but a little younger than expected.

Date lists:

REFERENCES

$\begin{array}{ll}\text { Bonn I } & \text { Scharpenseel, Pietig, and Tamers, 1968 } \\ \text { Groningen II } & \text { de Vries, Barendsen, and Waterbolk, 1958 } \\ \text { IVIC I } & \text { Tamers, 1965 } \\ \text { IVIC II } & \text { Tamers, 1966 } \\ \text { IVIC III } & \text { Tamers, 1967 } \\ \text { Michigan VII } & \text { Crane and Griffin, 1962 } \\ \text { Texas IV } & \text { Pearson, Iavis, and Tamers, 1966 } \\ \text { ICLA VII } & \text { Berger and Libby, 1968 } \\ \text { Yale IV } & \text { Deevey, Gralenski, and Hoffren, 1959 }\end{array}$

Berdichevsky, Scher, B., 1963, Publicación preliminar.: Rev. Antropología Santiago de Chile, no. 2, p. 65 .

Berger, Rainer and Libby, W. F., 1968 UCLA radiocarbon dates VII: Radiocarbon, v. 10 , p. $149-160$.

Broecker, W. S., Olson, Edwin A., and Bird, Junius, 1959, Radiocarbon measurements on samples of known age: Nature, v. 183, p. 1582-1584.

Crane, H. R. and Griffin, James B., 1962, University of Michigan radiocarbon dates VII: Radiocarbon, v. 4, p. 183-203.

Cruxent, José M., 1967, El paleo-indio en Taima-taima, estado Falcón, Venezuela: Acta Cient. Venezolana, Suppl. 3, p. 3-17.

Layrisse, Miguel and Wilbert, Johannes, 1966, Indian societies of Venezuela: Caracas, Fundación La Salle de Ciencias Naturales. 
Niemeyer, H. and Schiappacasse, V., 1963, Investigaciones arqueológicas en las terrazas de Conanoxa, Valle de Camarones, Provincia de Tarapacá: Rev. Univ. Año XLVIII.

Pearson, F. J., Jr., Davis, E. Mott, and Tamers, M. A., 1966, University of Texas radiocarbon dates IV: Radiocarbon, v. 8, p. 453-466.

Pietig, F. and Scharpenseel, H. W., 1966, Alterbestimmung mit dem Flüssigkeits-Szintillations-Spektrometer. Ein neuer Katalysator zur Benzolsynthese: Atompraxis, v. 12, p. $95-97$.

Rouse, Irving and Cruxent, J. M., 1963a, Venezuelan Archaeology: New Haven, Yale Univ. Press.

$1963 \mathrm{~b}$, Recientes datos sobre fechas arqueológicas por el método de $\mathbf{C}^{14}$ en el occidente de Venezuela: Acta Cient. Venezolana, Suppl. 1, p. 3-10.

Scharpenseel, H. W., Pietig, F., and Tamers, M. A., 1968, Bonn radiocarbon measurements I: Radiocarbon, v. 10, p. 8-28.

Schiappacasse, V. and Niemeyer, H., 1964, Excavaciones de un conchal en el pueblo de Guanaqueros, in: Arqueología de Chile Central y Areas Vecinas, p. 235.

Stuiver, Minze and Suess, H. E., 1966, On the relationship between radiocarbon dates and true sample ages: Radiocarbon, v. 8, p. 534-540.

Suárez, María Matilde, 1968, Los Warao: Caracas, Ed. Sucre.

Tamers, M. A., 1965, Instituto Venezolano de Investigaciones Científicas natural radiocarbon measurements I: Radiocarbon, v. 7, p. 54-65.

Tamers, M. A. and Pearson, F. J., Jr., 1965, Validity of radiocarbon dates on bone: Nature, v. 208, p. 1053-1055.

Tamers, M. A., 1966, Instituto Venezolano de Investigaciones Científicas natural radiocarbon measurements II: Radiocarbon, v. 8, p. 204-212.

1967a, Instituto Venezolano de Investigaciones Científicas natural radiocarbon measurements III: Radiocarbon, v. 9, p. 237-245.

$1967 \mathrm{~b}$, Evolution de la concentration du radiocarbone dans les basses latitudes de l'hémisphère Nord pendant les dernières années: Comptes Rendus, v. 264B, p. 344-347.

1969, Radiocarbon dating of recent events: Atompraxis, in press.

Taylor, R. E. and Berger, Rainer, 1967, Radiocarbon content of marine shells from the Pacific coasts of Central and South America: Science, v. 158, p. 1180-1182.

Vaquero, Antonio, 1965, Idioma Warao: Caracas, Ed. Sucre.

Vries, H. de, Barendsen, G. W., and Waterbolk, H. T., 1958, Groningen radiocarbon dates II: Science, v. 127, p. 129-137.

Wagner, Erika, 1967, The prehistory and ethnohistory of the Carache area in western Venezuela: Yale Univ. Publ. in Anthropol. No. 71.

Zucchi, Alberta, 1965, Informe preliminar de las excavaciones del yacimiento La Betania, estado Barinas, Venezuela: Boletín Indigenista Venezolano, v. 10, 155-168. 